\title{
Modeling photosynthetically active radiation: A review
}

\author{
Moisés Miguel Ángel NORIEGA GARDEA*, Luis Francisco CORRAL MARTÍNEZ, \\ Marcelino ANGUIANO MORALES, Gerardo TRUJILLO SCHIAFFINO and Didia Patricia SALAS PEIMBERT
}

División de Estudios de Posgrado e Investigación, Tecnológico Nacional de México/Instituto Tecnológico de Chihuahua, Av. Tecnológico 2909, 31200 Chihuahua, Chihuahua, México.

*Corresponding author; email: mmanoriegag@gmail.com

Received: July 12, 2019; accepted: June 9, 2020

\begin{abstract}
RESUMEN
La radiación fotosintéticamente activa (PAR) es importante en aplicaciones referentes a la fisiología de las plantas o el ciclo del carbono. No obstante, aún no se ha establecido una red global para su medición a pesar de su importancia. En este trabajo se revisa una serie de estudios referentes a la creación de modelos empíricos para la estimación de la radiación PAR en lugares donde no es medida con regularidad, utilizando para ello datos de parámetros meteorológicos y de radiación disponibles en estaciones meteorológicas. Se hace un listado de los modelos desarrollados, el sitio de estudio, los resultados obtenidos y la nomenclatura utilizada en cada uno de ellos. La manera más común de elaborar modelos empíricos de estimación es mediante el estudio de los cambios espaciotemporales en la relación entre la radiación PAR y la radiación solar global. Otros métodos de estimación incluyen el uso de productos derivados de satélites como los del satélite MODIS, así como el uso de redes neuronales artificiales. No obstante, a pesar de que estas últimas son más eficientes para la estimación de la radiación PAR, su uso no es tan extendido porque es más complejo que el desarrollo de modelos empíricos. La relación entre la radiación PAR y la radiación solar global alcanzó sus máximos en los meses de verano y los mínimos en los meses de invierno; además, los valores diarios por hora alcanzaron sus máximos al amanecer y al atardecer y sus mínimos alrededor del mediodía.
\end{abstract}

\begin{abstract}
Photosynthetically active radiation (PAR) is important in applications related to plant physiology or the carbon cycle. However, despite its importance, a global network for its measurement has not yet been established. This work consists of the revision of a series of works related to the development of empirical models for the estimation of PAR in places where it is not regularly measured, using for this purpose measurements of meteorological and radiation parameters available in weather stations. A list of the models developed, the study site, the results obtained, and the nomenclature used in each of them is made. The most common way to develop empirical estimation models is by studying spatio-temporal changes in the relationship between PAR and global solar radiation. Other estimation methods include the use of satellite-derived products such as MODIS-derived products and the use of artificial neural networks. Despite being more efficient for estimating PAR, the use of artificial neural networks is not as widespread because its use is more complex than the development of empirical models. The PAR to global solar radiation ratio reached its maximum in the summer months and the minimum in the winter months; in addition, the daily values per hour reached their maximum at sunrise and sunset, and their minimum around noon.
\end{abstract}

Keywords: photosynthetically active radiation, radiometry, estimation models, meteorological parameters. 


\section{Introduction}

Almost all energy harnessed on Earth is derived directly or indirectly from solar radiation. The fraction of solar radiation that is used most efficiently by various organisms for photosynthesis is called photosynthetically active radiation (PAR).

PAR corresponds to the radiation in the 400-700 nm waveband (McCree, 1972a, 1981). Photosynthetic photon flux density, $\mathrm{Q}_{\mathrm{p}}$, is defined as the photon flux density $\left(1 \mu \mathrm{mol}\right.$ photon $\mathrm{m}^{-2} \mathrm{~s}^{-1}=6.022 \times 10^{17}$ photon $\mathrm{m}^{-2} \mathrm{~s}^{-1}=1 \mu \mathrm{E}$ photon $\left.\mathrm{m}^{-2} \mathrm{~s}^{-1}\right)$ in the $400-700$ nm waveband (McCree, 1971).

$Q_{p}$ is an essential factor in providing energy for photosynthesis and other primary functions of green plants, which carry out the conversion of radiation energy into chemical energy. PAR is a crucial parameter to the surface energy cycle and the carbon cycle of terrestrial ecosystems. PAR plays an important role in terrestrial photosynthesis modeling, and in hydrological and agricultural studies (Niu et al., 2018).

Despite its importance, a global network for the measurement of PAR has not yet been established, even though it is an essential variable in terrestrial photosynthesis models ( $\mathrm{Hu}$ and Wang, 2012; Foyo-Moreno et al., 2018).

\subsection{History of PAR measurements}

Due to its importance, over the years photosynthetically active radiation has been the subject of study by various authors. Although other authors (Moon, 1940; Nichiporovich, 1960; Gulyaev, 1963) worked on this subject before McCree, he was the one who laid the foundations for a standard definition of photosynthetically active radiation. In 1966, he modified a solarimeter made by the Eppley Laboratory (Newport, USA) for the measurement of PAR. McCree relied on the idea of obtaining a standard response curve for green plants, similar to the response curve of the average human eye. This instrument was based on an electronic microvoltimeter with a glass hemisphere for the absorption of heat; it had a good performance in a phytotron, but due to its excessive fragility and size, it had a poor performance under crops. In this first approach of a sensor for measuring PAR flux the unit "watt $0.4-0.7 \mu \mathrm{m}$ " is abbreviated as "plantwatt," to create a new unit of measurement, while the irradiance figures are given in plantwatts $\times \mathrm{m}^{-2}$. In this study from McCree, the emphasis is placed on the need for a new unit of measurement, which is of adequate size and has a short name (McCree, 1966).

McCree (1971) found the same basic form on 22 leaves of different species of crop plants in their response curves, having two broad maxima, centered at 620 and $440 \mathrm{~nm}$, with a shoulder at $670 \mathrm{~nm}$; he also found a value of conversion between $Q_{p}(\mu \mathrm{mol}$ photon $\mathrm{m}^{-2} \mathrm{~s}^{-1}$ ) and irradiance $\left(\mathrm{W} \mathrm{m}^{-2}=\mathrm{J} \mathrm{m}^{-2} \mathrm{~s}^{-1}\right)$, having a value of $4.57 \pm 0.1 \mu \mathrm{mol} \mathrm{J}{ }^{-1}$ (McCree, $1972 a, b)$. This constant is used regularly to convert measurements of PAR that are made by radiometric instruments.

\section{Empirical models for the estimation of $Q_{p}$}

Photosynthetic photon flux density, $Q_{p}$, is often calculated as a fraction of the global solar radiation, $\mathrm{R}_{\mathrm{s}}$ (given in terms of irradiance, $\mathrm{W} \mathrm{m}^{-2}$ ). Numerous studies have been conducted for studying the seasonal variations of the $Q_{p} / R_{s}$ ratio. $Q_{p}$ and $R_{s}$, along with other measurable and calculable meteorological parameters like the clearness index, the solar elevation angle or the dewpoint temperature are used for the development of empirical models for the estimation of PAR.

The main goal of revised empirical models is the estimation of $Q_{p}$ under different sky conditions in places where it is not regularly observed. Some studies use satellite data for the estimation models of the $\mathrm{Q}_{\mathrm{p}} / \mathrm{R}_{\mathrm{s}}$ ratio, and others use artificial neural networks (ANN) for the development of the models. Models based on neural networks use parameters such as global irradiance, extraterrestrial irradiance, relative humidity, precipitable water, etc., as input data.

Foraknown radiation spectrum, $\mathrm{Q}_{\mathrm{p}}$ can be expressed by its equivalence of energy related units ( $\mathrm{W} \mathrm{m}^{-2}$, $\mathrm{MJ} \mathrm{m}^{-2}$ per day) or directly in photon related units $\left(\mu \mathrm{mol} \mathrm{m} \mathrm{m}^{-2} \mathrm{~s}^{-1}\right.$ ). Depending on this, there are generally two types of ratios used: $\mathrm{Q}_{\mathrm{p}} / \mathrm{R}_{\mathrm{s}}$ (unitless) and $\mathrm{Q}_{\mathrm{p}} / \mathrm{R}_{\mathrm{s}}$ $\left(\mu \mathrm{mol} \mathrm{J}{ }^{-1}\right.$, mol $\left.\mathrm{MJ}^{-1}\right)$. The first ratio can range in values from 0.44 (Zhang et al., 2000) to 0.55 (Hu et al., 2007), while the second from $1.69 \mathrm{~mol} \mathrm{MJ}^{-1}(\mathrm{Hu}$ and Wang, 2012) to $1.96 \mathrm{~mol} \mathrm{MJ}^{-1}$ (Xia et al., 2008).

\subsection{Parameters used for the development of empi- rical models}

The empirical models reviewed consider a set of parameters that can appropriately describe the sky 
conditions that influence the $\mathrm{Q}_{\mathrm{p}} / \mathrm{R}_{\mathrm{s}}$ ratio. The different parameters used in such models, their definitions and units are listed below:

Aerosol optical depth (AOD) (unitless): The quantitative estimate of the amount of aerosol present in the atmosphere. AOD measures the extinction of the light as it passes through the atmosphere (Xia et al., 2008; Li et al., 2010; Akitsu et al., 2015; Trisolino et al., 2018).

Aerosol transmittance ( $\tau$ ) (unitless): The degree to which the radiation passing through the atmosphere is absorbed by the aerosols present in it. It depends on the AOD and the optical air mass. It is calculated using Bouguer's law (Grant and Slusser, 2004).

Albedo $(\alpha)$ (unitless): The fraction of incident radiation that is reflected by a surface (Kathilankal et al., 2014).

Attenuation factor under clear skies ( $\rho_{\text {clear }}$ ) (unitless): The ratio of observed to extraterrestrial PAR under clear skies (Hu and Wang, 2013).

Clearness index $\left(k_{t}\right)$ (unitless): The ratio of total solar radiation to extraterrestrial solar radiation. It can also be defined as the ratio of the total irradiance on a horizontal surface to the extraterrestrial solar irradiance on a horizontal surface. It is used to characterize the sky and to evaluate the quality of the measured data of $\mathrm{R}_{\mathrm{s}}$ (Tsubo and Walker, 2005; Jacovides et al., 2009; Ge et al., 2010; Mizoguchi et al., 2013; Nwokolo et al., 2016; Foyo-Moreno et al., 2017, 2018).

Clearness of the sky ( $)$ and brightness of the skylight (4) (unitless): These two parameters are used to characterize sky conditions. They are calculated from the irradiance values and are defined as

$\epsilon=\left(R_{d}+R_{b}\right) / R_{d}$

$\Delta=R_{d} /\left(R_{b o} \sin \beta\right)$

where $R_{\mathrm{d}}$ is the diffuse irradiance, $R_{\mathrm{b}}$ is the direct normal irradiance, and $R_{\mathrm{bo}}$ is the extraterrestrial solar irradiance (Foyo-Moreno et al., 2017, 2018). Three categories of sky are regularly considered: (1) overcast $(\Delta<0.1, \varepsilon<0.2)$; (2) clear skies $(\Delta<0.1, \varepsilon$ $>5.2)$, and (3) intermediate skies $(0.2<\Delta<0.3$ and $1.2<\varepsilon<5.2$ ) (Pérez et al., 1990). The clearness of the sky depends on the cloud and aerosol amounts.
The brightness of the skylight depends on the aerosol burden and the cloud thickness (Alados et al., 1996).

Cloud index (n) (unitless): It is quantified from measurements derived from satellites of earth-atmospheric reflectivity, ground reflectivity, and maximum cloud reflectivity (Janjai et al., 2013).

Correction to the Sun-Earth distance $\left(E_{0}\right)$ (unitless): Ratio between the daily value of the Sun-Earth distance and its mean yearly value (Janjai et al., 2013).

Dewpoint temperature $\left(T_{\mathrm{d}}\right)\left({ }^{\circ} \mathrm{C}\right)$ : The temperature at which the water vapor contained in the air begins to condense producing dew or mist (Alados et al., 1996; Ge et al., 2010).

Diffuse irradiance $\left(R_{\mathrm{d}}\right)\left(W \mathrm{~m}^{-2}\right)$ : The amount of radiation received per unit area by a surface that has been scattered by molecules and particles in the atmosphere (Foyo-Moreno et al., 2018).

Diffuse PAR fraction ( $\left.Q_{\mathrm{dP}}\right)$ (unitless): Ratio of the diffuse PAR solar radiation to global PAR solar radiation (Jacovides et al., 2009).

Extraterrestrial global solar irradiance $\left(R s_{0}\right)$ $\left(W \mathrm{~m}^{-2}\right)$ : The solar irradiance at the top of the atmosphere, it is also called "solar constant" and its value is $1367 \mathrm{~W} \mathrm{~m}^{-2}$ (Nwokolo et al., 2016).

Extraterrestrial photosynthetic photon flux density $\left(Q_{\mathrm{p} 0}\right)\left(\mu \mathrm{mol} \mathrm{m} \mathrm{m}^{-2} \mathrm{~s}^{-1}\right)$ : It is the PAR photon flux at the top of the atmosphere. Is used to evaluate the data quality of the $Q_{p}$ measurements taken at the weather stations (Hu et al., 2007).

Extraterrestrial PAR constant $\left(Q_{\mathrm{ext}}\right)\left(\mu \mathrm{molm} \mathrm{m}^{-2} \mathrm{~s}^{-1}\right)$ : The value of $Q_{p}$ at the top of the atmosphere, it is taken as $45 \%$ of the solar irradiance at the top of the atmosphere, its value is $2776.412 \mu \mathrm{mol} \mathrm{m}^{-2} \mathrm{~s}^{-1}$ (Janjai et al., 2013).

Optical air mass (m) (unitless): A measure of the optical path length for light traveling from the Sun through the atmosphere to sea level relative to the optical path length traveled by light from the same source at the zenith (Janjai et al., 2013; Mizoguchi et al., 2013; Wang et al., 2013a, b; Niu et al., 2018).

PAR clearness index $\left(k_{\mathrm{tp}}\right)$ (unitless): The ratio between incident $\mathrm{Q}_{\mathrm{p}}$ and extraterrestrial $\mathrm{Q}_{\mathrm{p}}$ (Nwokolo et al., 2016).

$P A R$ irradiance $\left(Q_{\mathrm{PAR}}\right)\left(M J \mathrm{~m}^{-2} \mathrm{~s}^{-1}\right)$ : The number of the incident energy in the waveband of 400-700 nm per unit time on per unit surface (Zhang et al., 2000). 
Photometric radiation (iluminance) (L) (lux): Amount of luminous flux incident on a surface, per unit area (Tan and Ismail, 2015).

Photosynthetic photonflux density $\left(Q_{\mathrm{p}}\right)\left(\right.$ molm $\left.^{-2} s^{-1}\right)$ : The number of incident photons in the waveband of 400-700 nm per unit time and per unit surface (Zhang et al., 2000).

Precipitable water (w) ( $\mathrm{mm})$ : The total water vapor contained in a unit vertical column of the atmosphere (Wang et al., 2013b).

Relative humidity (RH) (unitless): The amount of water vapor present in air expressed as a percentage of the amount needed for saturation at the same temperature (Kathilankal et al., 2014; Nwokolo et al., 2016).

Relative sunshine $\left(S_{1}\right)$ (unitless): The ratio of measured and theoretical sunshine durations (Li et al., 2010).

Scattering factor $(\mathrm{Hd} / \mathrm{H})$ (unitless): The ratio between diffuse irradiance and global irradiance. It is used as an indicator of the scattering effect by the constituents in the atmosphere. It can represent the scattering associated with clouds, aerosols, rain, and so on (Bai, 2012).

Solar elevation angle ( $\beta)$ (degrees): The angle between the horizon and the center of the Sun's disc (Alados et al., 1996).

Solar zenith angle $(\theta)$ (degrees): The angle between the zenith and the center of the Sun's disc (Grant and Slusser, 2004; Bai, 2012; Janjai et al., 2013).

Sunshine duration $\left(L_{\mathrm{D}}\right)$ ( $s$ or $\left.h\right)$ : The sum of the time for which the direct solar irradiance exceeds $120 \mathrm{~W} \mathrm{~m}^{-2}$ (Hu et al., 2016a).

Total ozone column $\left(\mathrm{O}_{\mathrm{z}}\right)$ : The total amount of ozone in a column extending vertically from the Earth's surface to the top of the atmosphere (Janjai et al., 2013, 2015).

Visible irradiance (VIS) $\left(\mathrm{W} \mathrm{m}^{-2}\right)$ : The radiation in the 400-700 $\mathrm{nm}$ waveband, derived from the subtraction of measurements made with solar spectral radiation sensors in the 400-2800 and 700-2800 nm wavebands (Bai, 2012).

Water vapor pressure (e) (Pa): Related to atmospheric water vapor content. The pressure at which the gas phase of water is in equilibrium with the liquid phase. It is calculated using the relative humidity of the air (Mizoguchi et al., 2013; Aguiar et al., 2011).

\subsection{Models developed and results obtained}

A summary of the empirical models revised for this work is included in Tables I-III. Table I shows the parameters that are not defined in section 2.1. Table II shows the empirical models developed in the last 25 years, the location where the study took place, the results obtained and the application limits. Table III lists the studies that use methods where models cannot be reproduced or presented in a simple analytical way.

\section{Discussion}

The method based on empirical models to estimate $Q_{p}$ from meteorological parameters such as global solar radiation or the clearness index is the most reported in literature. However, these models have some limitations, among the most important is the solar elevation angle, which limits the quantity of data used for the development of the models. Another limitation in almost all models is that they are designed specifically for the site where the study took place or for weather conditions that are similar to the place of study. In order to be applicable to other sites, adjustments must be made to the models. An exception are the models developed by Foyo-Moreno et al. (2017, 2018), which were validated at sites with different climatic characteristics from the original sites of development (see "Valid to" column in Tables II and III).

The review of the developed models indicates that $Q_{p}$ can be reliably estimated using the clearness index and the solar elevation angle, which produce substantial changes in $\mathrm{Q}_{\mathrm{p}}$ and in the $\mathrm{Q}_{\mathrm{p}} / \mathrm{R}_{\mathrm{s}}$ ratio. The $Q_{p} / R_{s}$ ratio is also affected by other meteorological factors such as the solar zenith angle or dewpoint temperature.

Most of the publications reviewed report the same behavior of $Q_{p}$ : When the clearness index is high, the $Q_{p} / R_{s}$ ratio is lower, while this ratio is higher when the clearness index is low (see example in Figure 1a). The $\mathrm{Q}_{\mathrm{p}} / \mathrm{R}_{\mathrm{s}}$ ratio reaches its maximum values during the summer months and the lowest ones in the winter months (see example in Fig. 1b). This ratio exhibits its highest variability in autumn and winter months. There are few exceptions to this rule, for example $\mathrm{Yu}$ and Guo (2015) reported lower fractions in the summer months $\left(\mathrm{Q}_{\mathrm{p}} / \mathrm{R}_{\mathrm{s}}=0.416,0.44\right)$ and higher fractions in the winter months $\left(\mathrm{Q}_{\mathrm{p}} / \mathrm{R}_{\mathrm{s}}=0.47,0.49\right)$. 
Table I. Nomenclature used in empirical models for estimating PAR (in alphabetical order).

\begin{tabular}{|c|c|c|c|}
\hline Symbol & Name of the symbol & Symbol & Name of the symbol \\
\hline \multirow[t]{2}{*}{$\mathrm{D}_{368}$} & $\begin{array}{l}\text { Ratio of diffuse irradiance to global spectral } \\
\text { irradiance at } 368 \mathrm{~nm}\end{array}$ & $\mathrm{Q}_{\mathrm{pd}}$ & Daily cumulative $Q_{p}$ \\
\hline & Squared value of $\mathrm{D}_{368}$ & $\mathrm{R}_{\mathrm{s}, 368}$ & Global spectral irradiance at $368 \mathrm{~nm}$ \\
\hline $\mathrm{k}$ & $\begin{array}{l}\text { Absorption coefficient of water vapor in the } \\
\text { shortwave radiation }\end{array}$ & $\mu$ & Cosine of solar zenith angle \\
\hline $\mathrm{k}_{\mathrm{tD}}$ & Daily average value of $\mathrm{k}_{\mathrm{t}}$ & $\mu_{\mathrm{D}}$ & $\begin{array}{l}\text { Mean value of cosine of the solar zenith angle } \\
\text { from sunrise to sunset }\end{array}$ \\
\hline $\mathrm{L}_{\mathrm{D}}$ & Daytime duration & $\mu_{\mathrm{E}}$ & Cosine of solar zenith angle at noon \\
\hline $\mathrm{M}_{1}-\mathrm{M}_{4}$ & $\begin{array}{l}\text { Calibrated irradiance in the four channels } \\
\text { of the MFRSR at } 415,500,615 \text { and } 675 \mathrm{~nm}\end{array}$ & & \\
\hline \multicolumn{4}{|c|}{ Statistical parameters } \\
\hline MAE & Mean absolute error & RMSD & Root mean square deviation \\
\hline MBD & Mean bias difference & RMSE & Root mean square error \\
\hline MBE & Mean bias error & $\mathrm{R}^{2}$ & Coefficient of determination \\
\hline $\mathrm{RE}$ & Relative error & & \\
\hline
\end{tabular}

Depending on the location of the study, the maximum daily values are reported at sunrise and sunset and the minimum values around noon.

Models based on the use of satellite-derived products or the use of ANN report results that are in agreement with the empirical models. For example, $\mathrm{Yu}$ and Guo (2015) established models based on ANN, which consider meteorological information in the input layer, and reported that the $Q_{p} / R_{S}$ ratio generally decreases as the clearness index increases, which is consistent with the models developed by Alados et al. (1996).

\section{Conclusions}

In the present work, 50 papers and one book chapter related to the study of photosynthetically active radiation were reviewed, of which 41 provided information about the specific empirical models developed. This review focused on papers published in the last two decades in which the central theme is the estimation of $Q_{p}$ through the use of easily observable meteorological parameters. Older papers cited in this review provide a historical context on the measurement of PAR.

Although the studies of K.J. McCree are over 45 years old, they continue to be used as main references in works related to the study of PAR behavior. The clearest example is the frequent use of the conversion factor between quantum flux and energy flux, in both recent and older studies.

When studying the similarity of the results obtained with the models developed in each work analyzed (see Table IV), it can be said that the models can satisfactorily predict the behavior of PAR at the different study sites. Therefore, its use for estimating PAR in places where it is not measured regularly can offer a good alternative to PAR sensors when they are not available. The analysis of the seasonal variation of the $Q_{p} / R_{s}$ ratio and its dependence on meteorological parameters offers a better understanding of PAR in the study locations where the works analyzed in this document were carried out.

It is deduced from the estimation models (Table II) that the parameters most used for model development are the solar elevation angle and the clearness index. 
M. M. A. Noriega Gardea et al.

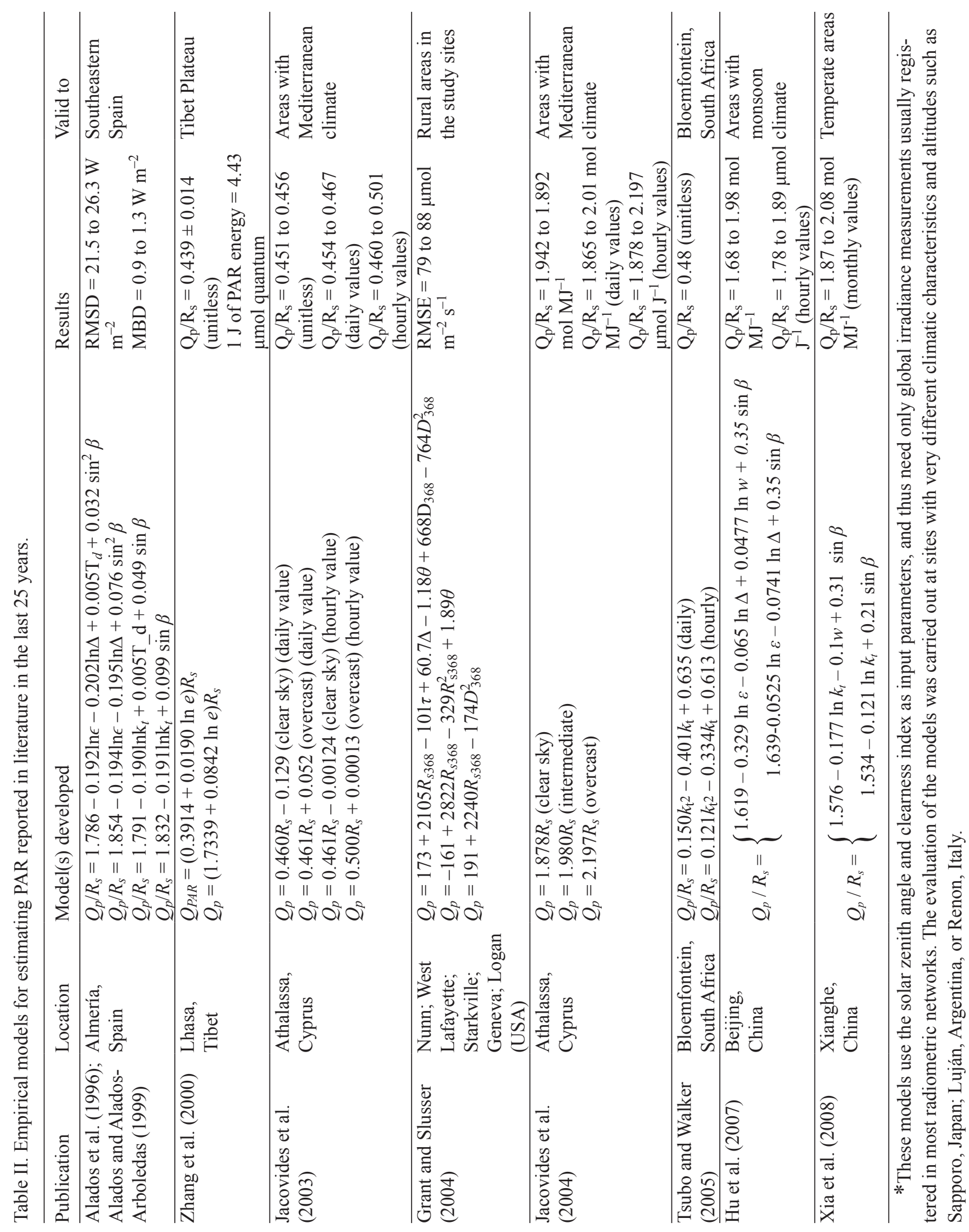




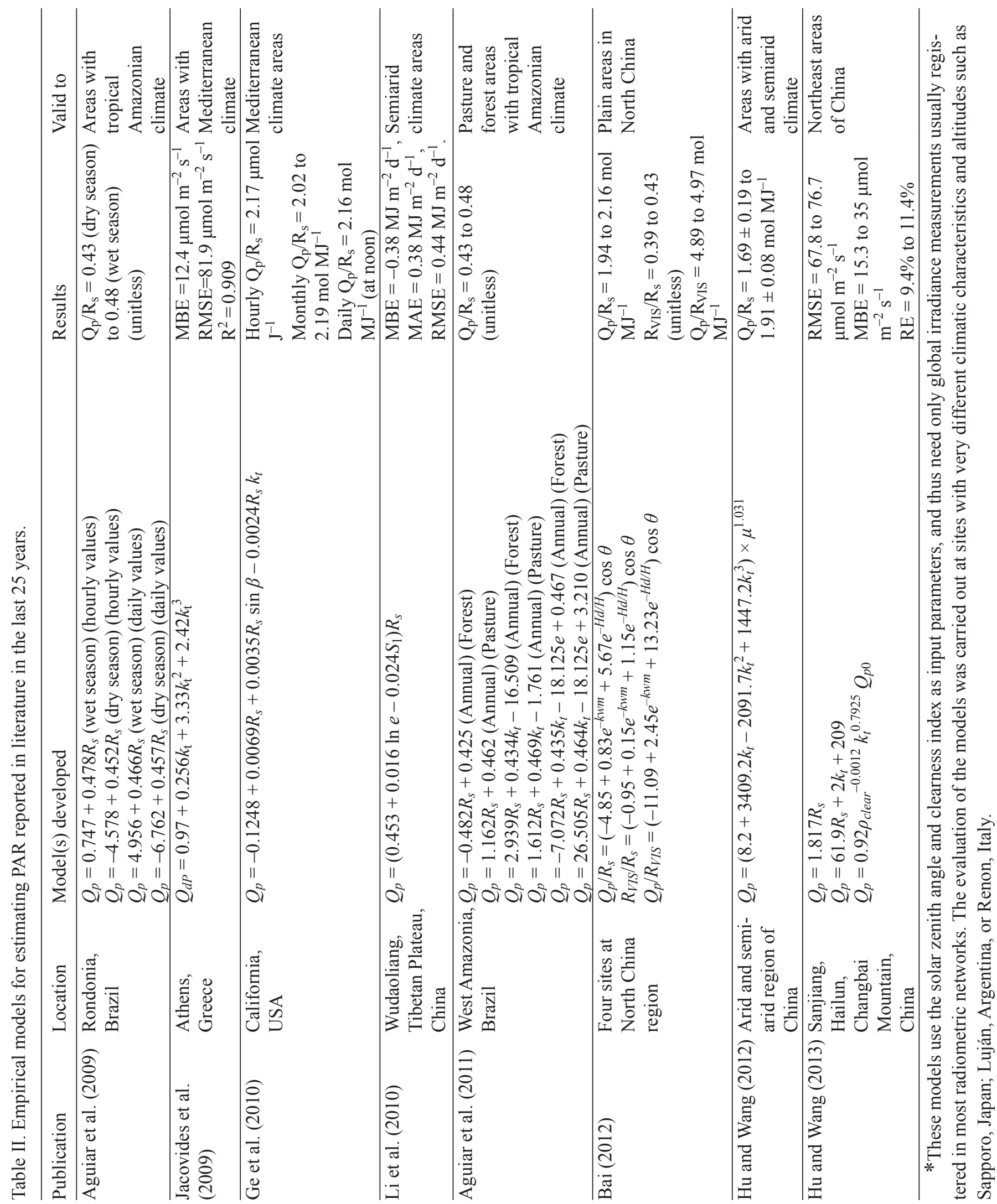


M. M. A. Noriega Gardea et al.

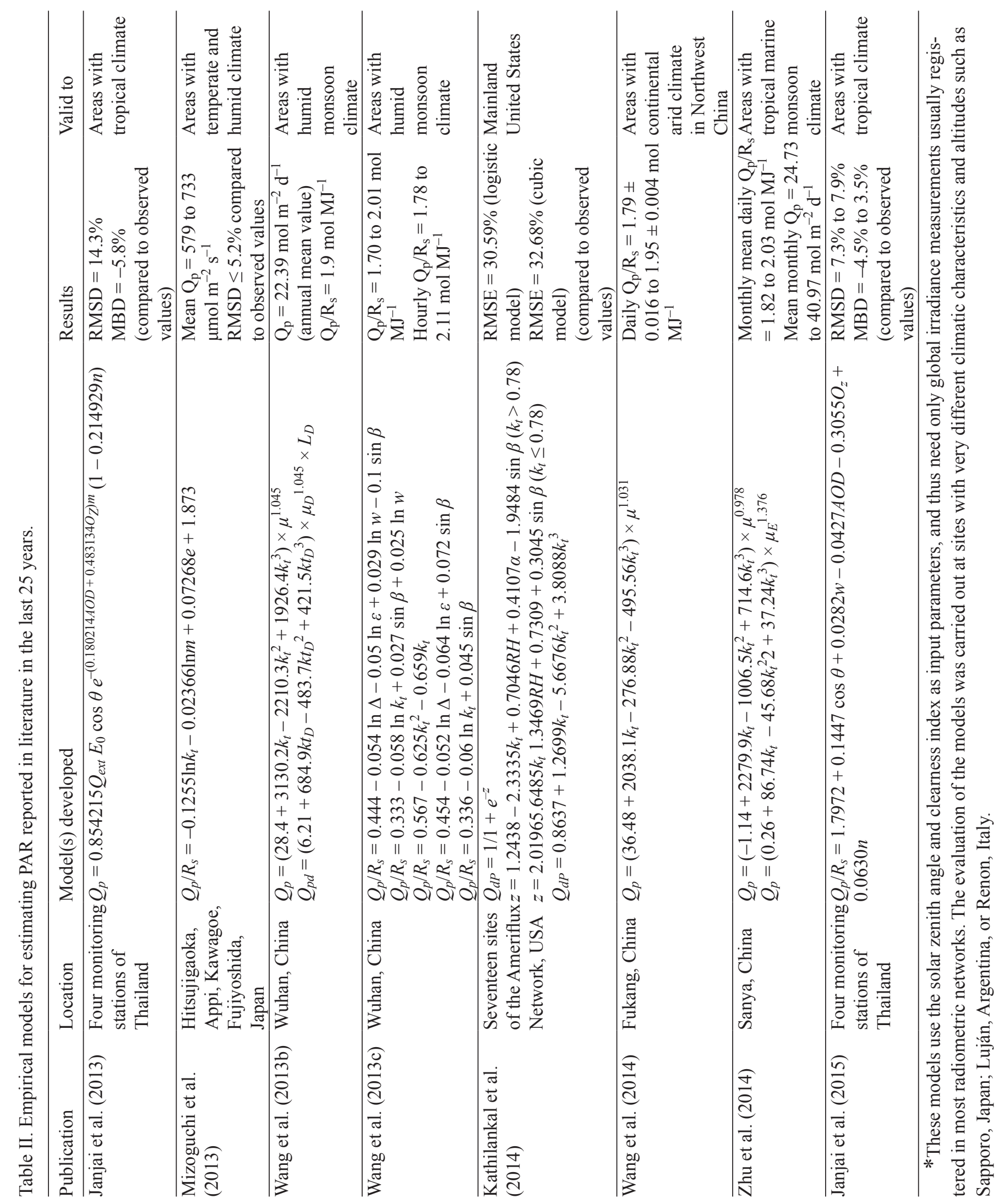




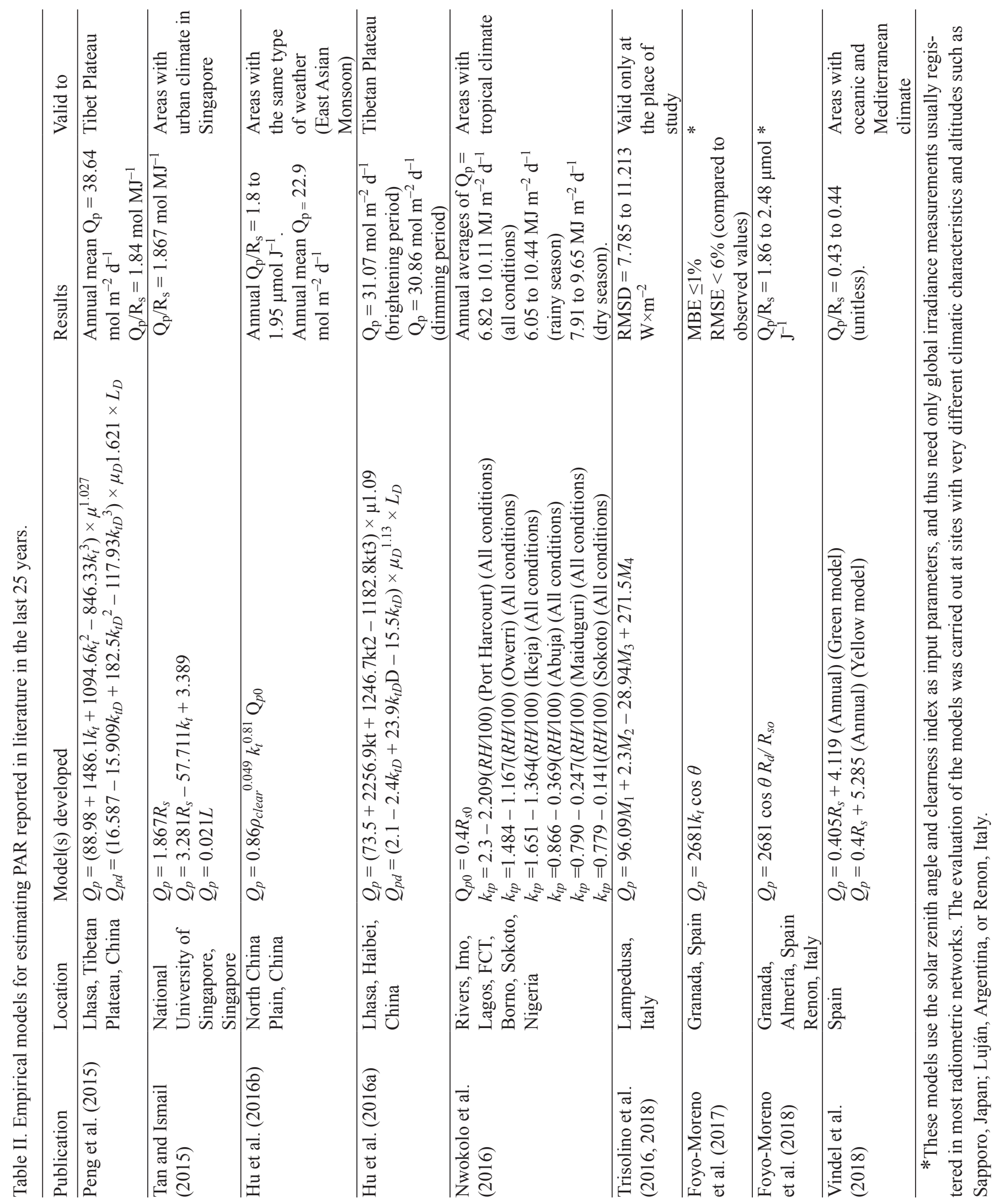


Table III. PAR estimation methods that cannot be reproduced or presented in a simple analytical way.

\begin{tabular}{|c|c|c|c|c|}
\hline Publication & Location & Technique used & Results & Valid to \\
\hline $\begin{array}{l}\text { Salim et al. } \\
(2014)\end{array}$ & Dehradun, India & $\begin{array}{l}\text { The PAR computation was } \\
\text { carried out using inputs from } \\
\text { MODIS derived products and } \\
\text { Microtops II sunphotometer } \\
\text { data }\end{array}$ & $\begin{array}{l}\text { Mean } Q_{p} \text { calculated with } \\
\text { Microtops } \mathrm{II}=304 \mathrm{~W} \mathrm{~m}^{-2} \\
\text { Mean } Q_{p} \text { calculated with } \\
\text { MODIS }=305 \mathrm{~W} \mathrm{~m}^{-2}\end{array}$ & $\begin{array}{l}\text { Dehradun and } \\
\text { surrounding area, } \\
\text { India }\end{array}$ \\
\hline $\begin{array}{l}\text { Akitsu et al. } \\
(2015)\end{array}$ & Tsukuba, Japan & $\begin{array}{l}\text { A PAR measurement system } \\
\text { is developed. The atmospheric } \\
\text { radiative transfer code Rstar6b } \\
\text { is used for the simulation of } \\
\text { radiation }\end{array}$ & $\begin{array}{l}\mathrm{Q}_{\mathrm{p}} / \mathrm{R}_{\mathrm{s}}=0.40 \text { to } 0.47 \\
\text { (unitless) }\end{array}$ & Tsukuba, Japan \\
\hline $\begin{array}{l}\text { Jacovides et al. } \\
(2015)\end{array}$ & $\begin{array}{l}\text { Athalassa, } \\
\text { Cyprus }\end{array}$ & $\begin{array}{l}\text { A multiple layer perceptron } \\
\text { (MLP) artificial network was } \\
\text { used for the estimation of PAR, } \\
\text { it used global solar radiation } \\
\text { and relative humidity as input } \\
\text { parameters }\end{array}$ & $\begin{array}{l}\text { Daily } \mathrm{Q}_{\mathrm{p}}=36.30 \text { to } 38.7 \\
\mathrm{~mol} \mathrm{~m}^{-2} \mathrm{~d}^{-1}\end{array}$ & $\begin{array}{l}\text { Areas with } \\
\text { Mediterranean } \\
\text { climate }\end{array}$ \\
\hline $\begin{array}{l}\text { Yu and Guo } \\
(2015)\end{array}$ & $\begin{array}{l}\text { Bondville, Sioux } \\
\text { Falls, USA }\end{array}$ & $\begin{array}{l}\text { A three-layer multiple layers } \\
\text { perceptron (MLP) artificial } \\
\text { network was used for the } \\
\text { estimation of PAR and the } \mathrm{Q}_{\mathrm{p}} / \\
\mathrm{R}_{\mathrm{s}} \text { ratio }\end{array}$ & $\begin{array}{l}\mathrm{Q}_{\mathrm{p}} / \mathrm{R}_{\mathrm{s}}=0.422 \text { (Bondville) } \\
\mathrm{Q}_{\mathrm{p}} / \mathrm{R}_{\mathrm{s}}=0.438 \text { (Sioux Falls) }\end{array}$ & $\begin{array}{l}\text { Rural and pasture } \\
\text { areas in the } \\
\text { midwestern USA }\end{array}$ \\
\hline Niu et al. (2018) & $\begin{array}{l}\text { Sixteen } \\
\text { meteorological } \\
\text { stations over } \\
\text { China }\end{array}$ & $\begin{array}{l}\text { Two adaptive network-based } \\
\text { fuzzy inference system } \\
\text { (ANFIS) PAR models } \\
\text { were developed with data } \\
\text { from measurements of } \\
\text { meteorological parameters as } \\
\text { input data }\end{array}$ & $\begin{array}{l}\text { Daily } Q_{p}=20.03 \text { to } 36.29 \\
\text { mol m}^{-2} \mathrm{~d}^{-1}\end{array}$ & Mainland, China \\
\hline
\end{tabular}
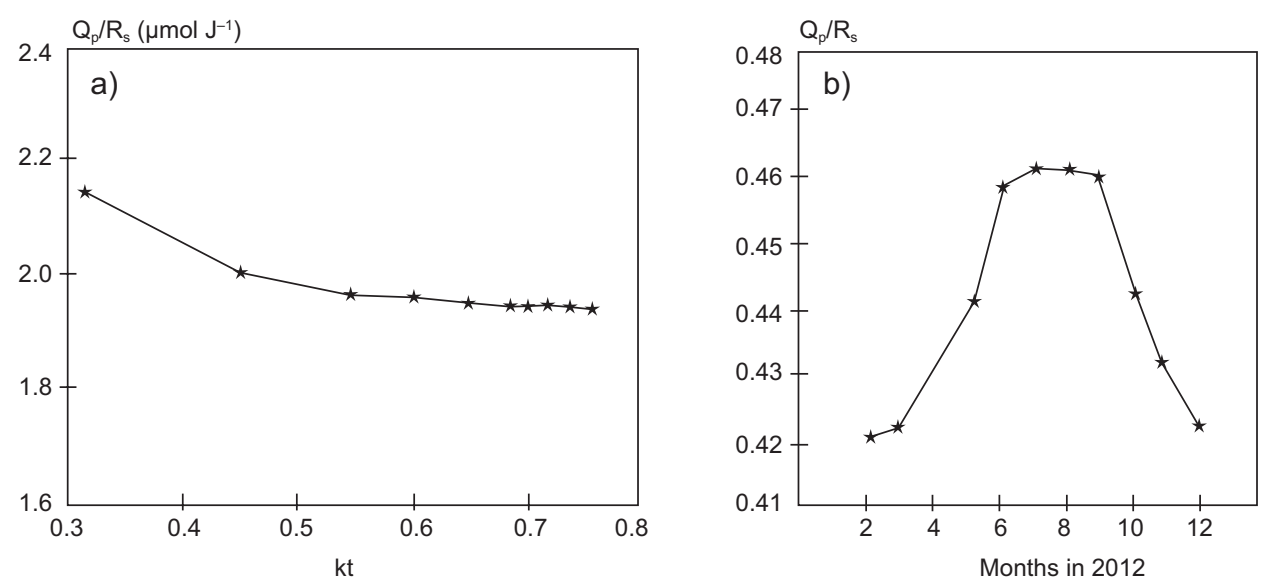

Fig. 1. (a) Example of the $\mathrm{Q}_{\mathrm{p}} / \mathrm{R}_{\mathrm{s}}$ ratio versus $\mathrm{k}_{\mathrm{t}}$ (extracted from Alados et al., 1996). (b) Example of monthly mean behavior of the $\mathrm{Q}_{\mathrm{p}} / \mathrm{R}_{\mathrm{s}}$ (extracted from Akitsu et al., 2015). 
Table IV. Comparison between some of the results obtained in the analyzed works. The complete results are shown in Tables II and III.

\begin{tabular}{lc}
\hline Publication & $\mathrm{Q}_{\mathrm{p}} / \mathrm{R}_{\mathrm{s}}$ ratio \\
\hline Jacovides et al. (2003) & 0.451 to 0.456 \\
Aguiar et al. (2009) & 0.43 to 0.48 \\
Akitsu et al. (2015) & 0.40 to 0.47 \\
Hu et al. (2007) & 1.78 to $1.89 \mu \mathrm{mol} \mathrm{J}$ \\
Hu et al. (2016) & 1.8 to $1.95 \mu \mathrm{mol} \mathrm{J}$ \\
Foyo-Moreno et al. (2018) & 1.86 to $2.48 \mu \mathrm{mol} \mathrm{J}$ \\
\hline
\end{tabular}

Thus, for a model to be reliable in estimating PAR, it must consider at least these two parameters. In order to achieve better precision, other parameters that affect the behavior of PAR such as dewpoint temperature and water vapor pressure must be included in the estimation model.

The models developed by Foyo-Moreno et al. $(2017,2018)$ depend only on the solar zenith angle and the clearness index, which are parameters regularly observed in meteorological stations, so its use is recommended anywhere where these parameters are observed in local stations. These models also have the advantage of being validated in sites that belong to both hemispheres with different climatic characteristics from the place used for their development.

Regarding specific climates, the models developed by Aguiar et al. (2011) can be used in areas with tropical climate since they use few parameters to estimate $\mathrm{Q}_{\mathrm{p}}$. In sites with temperate climates similar to central China, the models developed by Wang et al. $(2013 b, c)$ can be used to estimate $Q_{p}$. These models use parameters accessible at any meteorological station. The model developed by $\mathrm{Hu}$ and Wang (2012) uses only the cosine of the zenith solar angle and the clearness index, so it can be used in regions with arid and semi-arid climates. In general, the use of estimation models that use easily observable parameters at meteorological stations is recommended.

The estimation models are designed to work optimally at the study places because they are developed with local information, but they can be transferred to places with similar climatic conditions. Despite being able to be used at different places from the original sites of development, it is always recommendable to use local meteorological information develop new estimation models that are valid for the place of study.

\section{References}

Aguiar LJG, da Costa JMN, Aguiar RG, Fischer GR. 2009. Estimates and measurements of photosynthetically active radiation and global solar irradiance in Rondonia. AIP Conference Proceedings 1100: 435-438. https:// doi.org/10.1063/1.3117013

Aguiar LJG, Fischer GR, Ladle RJ, Malhado ACM, Justino FB, Aguiar RG, da Costa JMN. 2011. Modelling the photosynthetically active radiation in South West Amazonia under all sky conditions. Theoretical and Applied Climatology 108: 631-640. https://doi.org/10.1007/ s00704-012-0625-y

Akitsu T, Kume A, Hirose Y, Ijima O, Nasahara K. 2015. On the stability of radiometric ratios of photosynthetically active radiation to global solar radiation in Tsukuba, Japan. Agricultural and Forest Meteorology 209-210: 59-68. https://doi.org/10.1016/j. agrformet.2015.04.026

Alados I, Foyo-Moreno I, Alados-Arboledas L. 1996. Photosynthetically active radiation: Measurements and modelling. Agricultural and Forest Meteorology 78: 121-131. https://doi.org/10.1016/01681923(95)02245-7

Alados I, Alados-Arboledas L. 1999. Validation of an empirical model for photosynthetically active radiation. International Journal of Climatology 19: 1145-1152. https://doi.org/10.1002/(SICI)10970088(199908)19:10<1145::AID-JOC428>3.0.CO;2-3

Bai J. 2012. Observations and estimations of PAR and solar visible radiation in North China. Journal of Atmospheric Chemistry 69: 231-252. https://doi.org/10.1007/ s10874-012-9239-0

Foyo-Moreno I, Alados I, Alados-Arboledas L. 2017. A new conventional regression model to estimate hourly photosynthetic photon flux density under all sky conditions. International Journal of Climatology 37: 1067-1075. https://doi.org/10.1002/joc.5063

Foyo-Moreno I, Alados I, Alados-Arboledas L. 2018. A new empirical model to estimate hourly diffuse photosynthetic photon flux density. Atmospheric Research 203: 189-196. https://doi.org/10.1016/j. atmosres.2017.12.012 
Ge S, Smith RG, Jacovides CP, Kramer MG, Carruthers RI. 2010. Dynamics of photosynthetic photon flux density (PPFD) and estimates in coastal northern California. Theoretical and Applied Climatology 105: 107-118. https://doi.org/10.1007/s00704-010-0368-6

Gulyaev BI. 1963. Measurement of photosynthetically active radiation. Fiziol Rast 10: 513-524.

Grant RH, Slusser JR. 2004. Estimation of photosynthetic photon flux density from 368-nm spectral irradiance. Journal of Atmospheric and Oceanic Technology 21: 481-487. https://doi.org/10.1175/1520-0426(2004)02 $1<0481$ :EOPPFD $>2.0$. CO; 2

Hu B, Wang Y, Liu G. 2007. Measurements and estimations of photosynthetically active radiation in Beijing. Atmospheric Research 85: 361-371. https://doi. org/10.1016/j.atmosres.2007.02.005

Hu B, Wang Y. 2012. The climatological characteristics of photosynthetically active radiation in arid and semi-arid regions of China. Journal of Atmospheric Chemistry 69: 175-186. https://doi.org/10.1007/s10874-012-9235-4

Hu B, Wang Y. 2013. Comparison of multi-empirical estimation models of photosynthetically active radiation under all sky conditions in Northeast China. Theoretical and Applied Climatology 116: 119-129. https://doi. org/10.1007/s00704-013-0941-X

Hu B, Liu H, Wang Y. 2016a. Investigation of the variability of photosynthetically active radiation in the Tibetan Plateau, China. Renewable and Sustainable Energy Reviews 55: 240-248. https://doi.org/10.1016/j. rser.2015.10.155

Hu B, Yu Y, Liu Z, Wang Y. 2016b. Analysis of photosynthetically active radiation and applied parameterization model for estimating of PAR in the North China Plain. Journal of Atmospheric Chemistry 73: 345-362. https:// doi.org/10.1007/s10874-016-9330-z

Jacovides CP, Tymvios FS, Asimakopoulos DN, Theofilou KM, Pashiardes S. 2003. Global photosynthetically active radiation and its relationship with global solar radiation in the Eastern Mediterranean basin. Theoretical and Applied Climatology 74: 227-233. https://doi. org/10.1007/s00704-002-0685-5

Jacovides CP, Timvios FS, Papaioannou G, Asimakoupoulos DN, Theofilou CM. 2004. Ratio of PAR to broadband solar radiation measured in Cyprus. Agricultural and Forest Meteorology 121: 135-140. https://doi. org/10.1016/j.agrformet.2003.10.001

Jacovides CP, Boland J, Asimakoupoulos DN, Kaltsounides SA. 2009. Comparing diffuse radiation models with one predictor for partitioning incident PAR radiation into its diffuse component in the eastern Mediterranean basin. Renewable Energy 35: 1820-1827. https://doi.org/10.1016/j.renene.2009.11.015

Jacovides CP, Tymvios FS, Boland J, Tsitouri M. 2015. Artificial neural network models for estimating daily solar global UV, PAR and broadband radiant fluxes in an eastern Mediterranean site. Atmospheric Research 152: 138-145. https://doi.org/10.1016/j.atmosres.2013.11.004

Janjai S, Sripradit A, Wattan R, Buntoung S, Pattarapanitchai S, Masiri I. 2013. A simple semi-empirical model for the estimation of photosynthetically active radiation from satellite data in the tropics. International Journal of Photoenergy 2013: 1-6. https://doi. org/10.1155/2013/857072

Janjai S, Wattan R, Sripradit A. 2015. Modelling the ratio of photosynthetically active radiation to broadband global solar radiation using ground and satellite-based data in the tropics. Advances in Space Research 56: 2356-2364. https://doi.org/10.1016/j.asr.2015.09.020

Kathilankal JC, O'Halloran TL, Schmidt A, Hanson CV, Law BE. 2014. Development of a semi-parametric PAR (photosynthetically active radiation) partitioning model for the United States, version 1.0. Geoscientific Model Development 7: 2477-2484. https://doi.org/10.5194/ gmd-7-2477-2014

Li R, Zhao L, Ding Y, Wang S, Ji G, Xiao Y, Liu G, Sun L. 2010. Monthly ratios of PAR to global solar radiation measured at northern Tibetan Plateau, China. Solar Energy 84: 964-973. https://doi.org/10.1016/j. solener.2010.03.005

McCree KJ. 1966. A solarimeter for measuring photosynthetically active radiation. Agricultural Meteorology 3: 353-366. https://doi.org/10.1016/00021571(66)90017-3

McCree KJ. 1971. The action spectrum, absorptance and quantum yield of photosynthesis in crop plants. Agricultural Meteorology 9: 191-216. https://doi. org/10.1016/0002-1571(71)90022-7

McCree KJ. 1972a. Significance of enhancement for calculations based on the action spectrum for photosynthesis. Plant Physiology 49: 704-706. https://doi. org/10.1104/pp.49.5.704

McCree KJ. 1972b. Test of current definitions of photosynthetically active radiation against leaf photosynthesis data. Agricultural Meteorology 10: 443-453. https:// doi.org/10.1016/0002-1571(72)90045-3 
McCree KJ. 1981. Photosynthetically active radiation. In: Physiological plant ecology I. Encyclopedia of plant physiology (new series) (Lange OL, Nobel PS, Osmond CB, Ziegler H, Eds.). Springer, Berlin, 41-55. https://doi.org/10.1007/978-3-642-68090-8_3

Mizoguchi Y, Yasuda Y, Ohtani Y, Watanabe T, Kominami Y, Yamanoi K. 2013. A practical model to estimate photosynthetically active radiation using general meteorological elements in a temperate humid area and comparison among models. Theoretical and Applied Climatology 115: 583-589. https://doi.org/10.1007/ s00704-013-0912-2

Moon P. 1940. Proposed standard solar radiation curves for engineering use. Journal of the Franklin Institute 230: 583-617. https://doi.org/10.1016/S00160032(40)90364-7

Nichiporovich AA. 1960. Conference on measurement of visible radiation in plant physiology, agrometeorology and ecology. Fiziol Rast 7: 744-747.

Niu Z, Wang L, Niu Y, Hu B, Zhang M, Qin W. 2018. Spatiotemporal variations of photosynthetically active radiation and the influencing factors in China from 1961 to 2016. Theoretical and Applied Climatology 137: 2049-2067. https://doi.org/10.1007/s00704-018-2727-7

Nwokolo SC, Ogbulezie JC, Toge CK, John-Jaja SA. 2016. Modelling the influence of relative humidity on photosynthetically active radiation from global horizontal irradiation in six tropical ecological zones in Nigeria. New York Science Journal 9: 40-55. https:// doi.org/10.7537/marsnys091116.07

Peng S, Du Q, Lin A, Hu B, Xiao K, Xi Y. 2015. Observation and estimation of photosynthetically active radiation in Lhasa (Tibetan Plateau). Advances in Space Research 55: 1604-1612. https://doi.org/10.1016/j. asr.2015.01.002

Pérez R, Ineichen P, Seals R, Michalsky JJ, Stewart R. 1990. Modelling daylight availability and irradiance components from direct and global irradiance. Solar Energy 44: 271-289. https://doi.org/10.1016/0038092X(90)90055-H

Salim M, Mishra AK, Kant Y. 2014. Estimation of IPAR and direct forcing of aerosol over Dehradun and surrounding Area (India) using MODIS derived atmospheric products: A case study. Journal of the Indian Society of Remote Sensing 43: 181-187. https://doi. org/10.1007/s12524-014-0383-7

Tan PY, Ismail MRB. 2015. Photosynthetically active radiation and comparison of methods for its estimation in equatorial Singapore. Theoretical and Applied Climatology 123: 873-883. https://doi.org/10.1007/ s00704-015-1399-9

Trisolino P, Di Sarra A, Meloni D, Pace G. 2016. Determination of global and diffuse photosynthetically active radiation from a multifilter shadowband radiometer. Applied Optics 55: 8280-8286. https://doi.org/10.1364/ AO.55.008280

Trisolino P, di Sarra A, Anello F, Bommarito C, Di Iorio T, Meloni D, Monteleone F, Pace G, Piacentino S, Sferlazzo D. 2018. A long-term time series of global and diffuse photosynthetically active radiation in the Mediterranean: Interannual variability and cloud effects. Atmospheric Chemistry and Physics 18: $7985-$ 8000. https://doi.org/10.5194/acp-18-7985-2018

Tsubo M, Walker S. 2005. Relationships between diffuse and global solar radiation in southern Africa. Theoretical and Applied Meteorology 80: 17-25. https://doi. org/10.1007/s00704-004-0080-5

Vindel JM, Valenzuela RX, Navarro AA, Zarzalejo LF, Paz-Gallardo A, Souto JA, Méndez-Gómez R, Cartelle D, Casares JJ. 2018. Modelling photosynthetically active radiation from satellite-derived estimations over mainland Spain. Remote Sensing 10: 849-862. https:// doi.org/10.3390/rs10060849

Wang L, Gong W, Lin A, Hu B. 2013a. Analysis of photosynthetically active radiation under various sky conditions in Wuhan, Central China. International Journal of Biometeorology 58: 1711-1720. https://doi. org/10.1007/s00484-013-0775-3

Wang L, Gong W, Ma Y, Hu B, Zhang M. 2013b. Photosynthetically active radiation and its relationship with global solar radiation in Central China. International Journal of Biometeorology 58: 1265-1277. https://doi. org/10.1007/s00484-013-0690-7

Wang L, Gong W, Li Ch, Lin A, Hu B, Ma Y. 2013c. Measurement and estimation of photosynthetically active radiation from 1961 to 2011 in Central China. Applied Energy 111: 101-1017. https://doi.org/10.1016/j.apenergy.2013.07.001

Wang L, Gong W, Hu B, Zhu Z. 2014. Analysis of photosynthetically active radiation in Northwest China from observation and estimation. International Journal of Biometeorology 59:193-204. https://doi.org/10.1007/ s00484-014-0835-3

Xia X, Li Z, Wang P, Cribb M, Chen H, Zhao Y. 2008. Analysis of photosynthetic photon flux density and its parameterization in Northern China. Agricultural 
and Forest Meteorology 148: 1101-1108. https://doi. org/10.1016/j.agrformet.2008.02.008

Yu X, Guo X. 2015. Hourly photosynthetically active radiation estimation in Midwestern United States from artificial neural networks and conventional regressions models. International Journal of Biometeorology 60: 1247-1259. https://doi.org/10.1007/s00484-015$1120-9$
Zhang X, Zhang Y, Zhoub Y. 2000. Measuring and modelling photosynthetically active radiation in Tibet Plateau during April-October. Agricultural and Forest Meteorology 102: 207-212. https://doi.org/10.1016/ S0168-1923(00)00093-9

Zhu Z, Wang L, Gong W, Xiong Y, Hu B. 2014. Observation and estimation of photosynthetic photon flux density in Southern China. Theoretical and Applied Climatology 120: 701-712. https://doi.org/10.1007/ s00704-014-1204-1 